\title{
Respon Karakter Pengisian Biji dan Hasil terhadap Pemberian Pupuk Urea pada Empat Varietas Padi
}

\author{
Response of Grain Filling and Yield Traits to Nitrogen Levels in Four Varieties of Rice \\ Renica Nurhermawati ${ }^{1}$, Iskandar Lubis ${ }^{2 *}$, dan Ahmad Junaedi ${ }^{2}$ \\ ${ }^{1}$ Program Studi Agronomi dan Hortikultura, Sekolah Pascasarjana, Institut Pertanian Bogor \\ ${ }^{2}$ Departemen Agronomi dan Hortikultura, Fakultas Pertanian, Institut Pertanian Bogor \\ (IPB University), Jl. Meranti, Kampus IPB Darmaga, Bogor 16680, Indonesia
}

Diterima 23 September 2021/Disetujui 6 Desember 2021

\begin{abstract}
Nitrogen $(N)$ plays an important role in rice plants including in increasing crop yields. The difference in grain yields observed in each rice variety is closely related to the grain filling trait. Thus, the response of the grain filling and yield traits from different rice varieties under different $N$ conditions in the soil is relevant to study. The purpose of this study was to evaluate the response of grain filling and yields characters of four rice varieties to the application of urea fertilizer. This study was conducted in the rice fields of Petapahan Village, Kampar District, Riau Province from September to December 2020. The field experiment was arranged in a split-plot design with whole plots arranged as randomized complete block design. The dose of urea fertilizer (0 $\mathrm{kg} \mathrm{ha}^{-1}$ and $\left.250 \mathrm{~kg} \mathrm{ha}^{-1}\right)$ was the first factor as the main plot, while varieties (Hipa 18, IPB 3S, Ciherang and Way Apo Buru) were the second ones as sub-plots. Results showed that Hipa 18 was a rice variety that remobilizes the highest assimilate during the seed filling stage. Hipa 18 also showed the highest percentage of $N$ usage for panicle formation and development in comparison to other rice varieties. Overall, the highest response for all yield components was also obtained from Hipa 18 except for the 100-seed weight. The results of this study can be used as a basis in breeding new rice varieties possessing high yield trait. In addition, a precise fertilization for each rice variety can be recommended.
\end{abstract}

Keywords: assimilate remobilization, dry weight, leaf area index, leaf $N$ content, photosynthesis

\section{ABSTRAK}

Unsur nitrogen (N) memainkan peran penting pada tanaman padi termasuk dalam meningkatkan hasil tanaman. Terdapatnya perbedaan hasil gabah pada masing-masing varietas padi sangat erat kaitannya dengan karakter pengisian biji. Dengan demikian, respon karakter pengisian biji dan hasil dari varietas padi yang berbeda terhadap kondisi $N$ di dalam tanah sangat relevan untuk dikaji. Tujuan penelitian ini adalah untuk mengkaji respon karakter pengisian biji dan hasil empat varietas padi terhadap pemberian pupuk urea. Penelitian ini dilaksanakan di lahan persawahan Desa Petapahan, Kampar, Riau pada bulan September sampai Desember 2020. Rancangan percobaan yang digunakan adalah rancangan

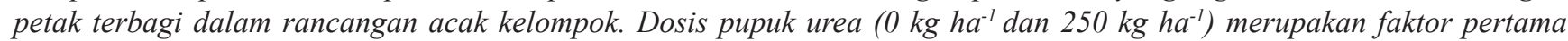
sebagai petak utama, sedangkan varietas (Hipa 18, IPB 3S, Ciherang dan Way Apo Buru) merupakan faktor kedua sebagai anak petak. Berdasarkan hasil penelitian diketahui bahwa Hipa 18 merupakan varietas padi yang melakukan remobilisasi asimilat dalam jumlah yang paling banyak selama fase pengisian biji. Selain itu, Hipa 18 juga menggunakan $N$ dalam persentase yang paling tinggi untuk pembentukan dan perkembangan malai dibandingkan varietas lainnya. Respon tertinggi untuk semua komponen hasil juga diperoleh dari Hipa 18 kecuali bobot 100 biji. Hasil penelitian ini dapat digunakan sebagai dasar dalam merakit varietas padi yang memiliki karakterisik hasil tinggi. Disamping itu, pemupukan yang presisi untuk masing-masing varietas padi dapat direkomendasikan.

Kata kunci: bobot kering, fotosintesis, indeks luas daun, kandungan $N$ daun, remobilisasi asimilat

* Penulis untuk korespondensi. e-mail: iskandarlbs@apps.ipb.ac.id 


\section{PENDAHULUAN}

Tantangan pemenuhan pangan akan terus dihadapi mengingat banyaknya permasalahan yang ada. Selain pertumbuhan penduduk, menurutElizabeth(2011) degradasi, alih fungsi, dan kompetisi penggunaan lahan juga menjadi tantangan tersendiri. Oleh karena itu, peningkatan hasil tidak bisa lagi bertumpu pada perluasan lahan, melainkan melalui upaya peningkatan produktivitas, diantaranya adalah penggunaan varietas padi yang memiliki potensi hasil tinggi. Namun terdapatnya permasalahan degradasi lahan menyebabkan potensi hasil yang tinggi ini sering tidak tercapai secara optimal. Dengan demikian, pemahaman terhadap karakter pengisian biji pada tanaman padi sangat diperlukan sehingga apa yang harus dilakukan untuk mengoptimalkan hasil tanaman dapat diketahui. Karakter hasil tanaman itu sendiri sangat dipengaruhi oleh beberapa faktor, seperti lingkungan, genotip, dan interaksi antara keduanya (Kartina et al., 2016). Lingkungan yang optimum akan mendorong terbentuknya hasil yang maksimal sesuai dengan kemampuan genetik suatu tanaman. Salah satu faktor lingkungan yang sangat penting untuk dikaji adalah kandungan nitrogen $(\mathrm{N})$ di dalam tanah.

Nitrogen berkontribusi pada pengisian biji karena keberadaannya di dalam tanah sangat mempengaruhi fotosintesis dan remobilisasi asimilat setelah heading (50\% berbunga) (Li et al., 2017). Pupuk $\mathrm{N}$ yang sesuai dapat meningkatkan produksi bahan kering yang disimpan di dalam batang (Liang et al., 2017). Huang et al. (2019) menambahkan bahwa hasil tinggi pada tanaman salah satunya dapat disebabkan oleh akumulasi $\mathrm{N}$ yang tinggi setelah tanaman memasuki fase pembungaan. Varietas padi yang berbeda memiliki respon pertumbuhan dan hasil yang berbeda pula terhadap kondisi N. Setiap varietas membawa sifat genetik yang berbeda sehingga akan menunjukkan interaksi yang berbeda dengan kondisi lingkungannya. Tujuan penelitian ini adalah untuk mengkaji respon karakter pengisian biji dan hasil empat varietas padi terhadap pemberian pupuk urea.

\section{BAHAN DAN METODE}

Penelitian ini dilaksanakan di lahan persawahan petani di Desa Petapahan, Kabupaten Kampar, Provinsi Riau pada bulan September sampai Desember 2020. Curah hujan bulanan, kelembaban, dan suhu rata-rata di lokasi penelitian, secara berturut-turut adalah $242.15 \mathrm{~mm}, 83.71 \%$, dan 26.88 ${ }^{\circ} \mathrm{C}$ dengan $\mathrm{pH}$ tanah 4.29 (sangat masam), C organik 3.16\% (tinggi) $\mathrm{N} 0.21 \%$ (sedang), $\mathrm{P}_{2} \mathrm{O}_{5} 188.8 \mathrm{mg}$ per $100 \mathrm{~g}$ sampel (sangat tinggi), dan $\mathrm{K}_{2} \mathrm{O} 5 \mathrm{mg}$ per $100 \mathrm{~g}$ sampel (sangat rendah).

Rancangan percobaan yang digunakan adalah rancangan petak terbagi (RPT) dalam rancangan acak kelompok (RAK) dengan 2 faktor dan 3 kelompok sehingga terdapat 24 satuan percobaan dengan petak percobaan berukuran $4 \mathrm{~m} \mathrm{x} 4 \mathrm{~m}$. Faktor pertama sebagai petak utama adalah dosis urea, terdiri dari $0 \mathrm{~kg} \mathrm{ha}^{-1}$ dan $250 \mathrm{~kg} \mathrm{ha}^{-1}$. Faktor kedua sebagai anak petak adalah varietas, yaitu Hipa 18, IPB 3S, Ciherang, dan Way Apo. Pemupukan P diberikan dengan takaran $80 \mathrm{~kg}$ TSP ha ${ }^{-1}$ pada $10 \mathrm{HST}$, sedangkan K diberikan dalam 2 tahap, yaitu pada 10 dan 30 HST masingmasing sebanyak $50 \mathrm{~kg} \mathrm{KCl} \mathrm{ha}^{-1}$. Pada perlakuan urea 250 $\mathrm{kg} \mathrm{ha}^{-1}$,pemupukan dilakukan dalam 3 tahap, yaitu pada 10 , 30, dan 45 HST, masing-masing sebesar 75,100, dan $75 \mathrm{~kg}$ $\mathrm{ha}^{-1}$. Benih yang telah berumur 18 hari setelah semai yang berasal dari empat varietas padi ditanam dengan sistem jajar legowo 2 : 1 dengan jarak tanam $25 \times 12.5$ x $50 \mathrm{~cm}$ dengan jumlah benih per lubang tanam adalah sebanyak 3 benih.

Pengamatan pertumbuhan dilakukan terhadap karakter tinggi tanaman (TT) (cm), jumlah anakan (JA), bobot kering tajuk (BKT) (g), indeks luas daun (ILD), kandungan $\mathrm{N}$ daun (\%) menggunakan metode Kjeldahl, Non-Structural Carbohydrate (NSC) (g) menggunakan metode Longland dan Byrd (2006), dan klorofil ( $\mu$ mol m ${ }^{-2}$ ) menggunakan Portable Chlorophyll Meter model YLS-A. Pengamatan terhadap karakter tinggi tanaman dan jumlah anakan masing-masing dilakukan dalam selang waktu sekali dalam dua minggu. Pengamatan tinggi tanaman juga dilakukan pada stadi heading ( $50 \%$ berbunga) dan panen, sedangkan pengamatan terhadap jumlah anakan dilakukan sampai fase terbentuknya anakan maksimum padi. Sementara itu, untuk karakter BKT, ILD, serta klorofil dilakukan pada fase inisiasi malai, heading (50\% berbunga), heading +20 hari, dan panen. Kandungan $\mathrm{N}$ daun diamati pada saat tanaman memasuki fase inisiasi malai dan heading. NSC diamati saat heading, heading +20 hari, dan panen. Panen dilakukan pada kondisi $90-95 \%$ biji padi sudah menguning pada tiap satuan percobaan. Pengamatan hasil dan komponen hasil yang dilakukan setelah panen yaitu jumlah malai, bobot 100 biji (g), jumlah biji per rumpun, bobot biji per rumpun $(\mathrm{g})$, dan bobot biji bernas per rumpun $(\mathrm{g})$.

Analisis data dilakukan dengan uji analysis of variance dan Duncan's multiple range test pada taraf 5\% menggunakan software R. Selanjutnya, untuk mengetahui apakah terhadapt hubungan antar karakter yang diamati, dilakukan uji korelasi berganda berdasarkan metode Pearson.

\section{HASIL DAN PEMBAHASAN}

\section{Pertumbuhan Padi dan Pengisian Biji}

Tinggi tanaman dan jumlah anakan memperlihatkan perbedaan morfologis akibat perbedaan varietas. Hal ini terjadi karena varietas yang berbeda membawa sifat genetik, fisiologi, dan morfologi yang berbeda pula yang akan mempengaruhi keragaman penampilan tanaman (Alavan et al., 2015) (Tabel 1). Pada penelitian ini, varietas padi IPB 3S menunjukkan tinggi tanaman tertinggi yang berbeda nyata dibandingkan tiga varietas lainnya, namun pada karakter jumlah anakan terbanyak ditunjukkan oleh varietas Hipa 18. Fenomena ini berhubungan dengan sifat dari masingmasing tipe padi, dimana IPB 3S merupakan padi tipe baru yang memiliki sifat tinggi dan memiliki jumlah anakan lebih sedikit dibandingkan tiga varietas lainnya namun anakan yang dihasilkan bersifat produktif, sedangkan Hipa 18 merupakan padi hibrida yang memiliki jumlah anakan lebih banyak. 
Nitrogen dalam jumlah yang cukup pada perlakuan $250 \mathrm{~kg} \mathrm{ha}^{-1}$ urea terbukti dapat mendukung pembentukan sel pada organ tanaman serta dapat mengoptimalkan proses fotosintesis sehingga dapat menyediakan asimilat yang cukup untuk pertambahan tinggi dan perbanyakan jumlah anakan tanaman (Tabel 1). Hal tersebut dikarenakan selain merupakan komponen utama klorofil, nitrogen juga berperan dalam metabolisme penting dalam sel, dan berperan baik secara genetik maupun struktural (Vijayalakshmi et al., 2013) sehingga dampak dari kekurangan unsur nitrogen akan sangat terlihat secara morfologis.

Morfologi tanaman yang baik dapat dihasilkan sebagai akibat pembentukan bahan kering tanaman yang optimal. Bahan kering merepresentasikan akumulasi senyawa organik yang berhasil disintesis oleh tanaman, atau yang lebih dikenal sebagai non-structural carbohydrate (NSC) yang terdiri dari gula terlarut dan pati dan sebagian besar disimpan di batang (Wang et al., 2017). Penyimpanan NSC ini menjadi aspek fisiologis yang sangat penting dalam siklus hidup tanaman, karena akan mempengaruhi hasil, toleransi terhadap cekaman, hingga produksi bahan bakar nabati (Slewinski, 2012).

Hasil penelitian ini juga menunjukkan bahwa Hipa 18 memiliki bobot kering total yang paling tinggi pada semua fase tanaman dan penurunan bobot kering batang dan daun yang paling tinggi pada heading hingga panen (Tabel 2). Penurunan bobot kering batang dan daun mengindikasikan terjadinya remobilisasi asimilat selama masa pengisian biji tanaman padi. Varietas ini juga mampu meremobilisasi NSC pada fase heading pada saat varietas padi IPB 3S, Ciherang, dan Way Apo Buru masih dalam tahapan mengakumulasi NCS (Tabel 3). Hal ini mengindikasikan bahwa hasil fotosintesis pada Hipa 18 sudah tidak dapat mencukupi kebutuhan asimilat untuk pengisian biji mulai dari fase heading, sementara hasil fotosintesis dari ketiga varietas lainnya masih dapat disimpan dalam bentuk NSC setelah memenuhi kebutuhan pengisian biji. Ukuran sink (organ yang menyimpan asimilat) dan kemampuan tanaman dalam menghasilkan bahan kering selama masa pengisian biji menjadi faktor pembeda jumlah asimilat yang diremobilasasi pada tiap varietas. Berdasarkan jumlah biji per rumpun yang dihasilkan, Hipa 18 memiliki ukuran sink yang paling besar dibandingkan varietas lainnya(Tabel 6). Dengan demikian dalam pemenuhan kebutuhan sink tersebut, dibutuhkan remobilisasi asimilat dari batang dan daun yang lebih banyak untuk membantu fotosintesis dalam mengisi biji selama fase pengisian biji.

Lubis et al. (2013) mengemukakan bahwa sebagian besar variasi produksi bahan kering antar kultivar baik pada fase reproduktif ataupun fase pengisian biji disebabkan oleh efisiensi penggunaan cahaya. Li et al. (2012) menambahkan bahwa efisiensi penggunaan cahaya yang tinggi didorong oleh keadaan $\mathrm{N}$ yang optimal. Efisiensi penggunaan cahaya yang tinggi dapat membantu peningkatan hasil fotosintesis yang merupakan proses pembentukan bahan kering. Hasil penelitian ini membuktikan bahwa keberadaan unsur $\mathrm{N}$ mampu mempengaruhi laju fotosintesis, tentunya juga mempengaruhi faktor-faktor yang yang memainkan peran dalam menentukan tinggi dan rendahnya hasil fotosintesis, seperti kandungan $\mathrm{N}$ daun (Tabel 4), klorofil, dan ILD (Tabel 5). Oleh karena itu, jumlah bahan kering yang diproduksi bergantung pada ketersediaan unsur N. Hal ini sejalan dengan hasil penelitian Xi dan Yong (2016) yang mengungkapkan bahwa kondisi $\mathrm{N}$ yang cukup pada media akan meningkatkan kandungan $\mathrm{N}$ daun, klorofil, konduktansi stomata, konduktansi mesofil, dan laju fotosintesis pada tanaman padi.

Hasil pengamatan pada kandungan $\mathrm{N}$ daun yang dilakukan pada inisiasi malai dan heading menunjukkan adanya interaksi antara kedua faktor tersebut (Tabel 4). Hal ini menjadi menarik karena pada pemberian urea $250 \mathrm{~kg} \mathrm{ha}^{-1}$, Hipa 18 memiliki persentase kandungan $\mathrm{N}$ daun tertinggi pada saat tanaman padi memasuki fase inisiasi malai, namun nilainya menjadi yang paling rendah pada masa heading dan berbeda nyata dengan Ciherang dan Way Apo Buru. Fenomena ini mengindikasikan terdapatnya penggunaan $\mathrm{N}$ yang besar dalam pembentukan dan perkembangan malai pada varietas tersebut. Pada Hipa 18 dan IPB 3S, adanya input $\mathrm{N}$ dari $250 \mathrm{~kg} \mathrm{ha}^{-1}$ pupuk urea menyebabkan penurunan persentase $\mathrm{N}$ daun yang lebih tinggi dibandingkan dengan

Tabel 1. Penampilan karakter tinggi tanaman dan jumlah anakan dari empat varietas padi pada pemberian pupuk urea

\begin{tabular}{lcccccccc}
\hline \multirow{2}{*}{$\begin{array}{l}\text { Dosis urea dan } \\
\text { varietas }\end{array}$} & \multicolumn{4}{c}{ Tinggi tanaman $(\mathrm{cm})$} & \multicolumn{3}{c}{ Jumlah anakan } \\
\cline { 2 - 8 } & $2 \mathrm{MST}$ & $4 \mathrm{MST}$ & $6 \mathrm{MST}$ & Berbunga & Panen & 2 MST & 4 MST & $6 \mathrm{MST}$ \\
\hline Dosis urea & & & & & & & \\
$0 \mathrm{~kg} \mathrm{ha}^{-1}$ & $29.52 \mathrm{a}$ & $44.98 \mathrm{~b}$ & $51.88 \mathrm{~b}$ & $67.70 \mathrm{~b}$ & $80.56 \mathrm{~b}$ & $4.22 \mathrm{a}$ & $12.73 \mathrm{~b}$ & $13.73 \mathrm{~b}$ \\
$250 \mathrm{~kg} \mathrm{ha}^{-1}$ & $31.00 \mathrm{a}$ & $50.75 \mathrm{a}$ & $65.57 \mathrm{a}$ & $85.02 \mathrm{a}$ & $96.02 \mathrm{a}$ & $6.18 \mathrm{a}$ & $19.35 \mathrm{a}$ & $19.6 \mathrm{a}$ \\
Varietas & & & & & & & & \\
Hipa 18 & $32.45 \mathrm{a}$ & $48.84 \mathrm{~b}$ & $60.09 \mathrm{~b}$ & $78.65 \mathrm{~b}$ & $91.71 \mathrm{ab}$ & $5.97 \mathrm{a}$ & $19.93 \mathrm{a}$ & $20.23 \mathrm{a}$ \\
IPB 3S & $31.81 \mathrm{a}$ & $55.01 \mathrm{a}$ & $68.11 \mathrm{a}$ & $91.98 \mathrm{a}$ & $99.45 \mathrm{a}$ & $4.10 \mathrm{~b}$ & $10.38 \mathrm{c}$ & $10.73 \mathrm{c}$ \\
Ciherang & $29.19 \mathrm{a}$ & $43.67 \mathrm{c}$ & $54.64 \mathrm{c}$ & $65.95 \mathrm{c}$ & $83.74 \mathrm{bc}$ & $6.10 \mathrm{a}$ & $16.55 \mathrm{~b}$ & $17.90 \mathrm{~b}$ \\
Way Apo Buru & $27.64 \mathrm{a}$ & $43.94 \mathrm{c}$ & $52.05 \mathrm{c}$ & $68.84 \mathrm{c}$ & $78.26 \mathrm{c}$ & $4.63 \mathrm{~b}$ & $17.29 \mathrm{ab}$ & $17.80 \mathrm{~b}$ \\
\hline
\end{tabular}

Keterangan: Angka yang diikuti huruf yang sama pada kolom yang sama menunjukkan hasil yang tidak berbeda nyata berdasarkan DMRT pada $\alpha=5 \%$. MST $=$ minggu setelah tanam 
Tabel 2. Bobot kering tajuk empat varietas padi selama fase pengisian biji pada pemberian pupuk urea

\begin{tabular}{|c|c|c|c|c|c|c|c|c|}
\hline \multirow{2}{*}{$\begin{array}{l}\text { Dosis urea dan } \\
\text { varietas }\end{array}$} & \multicolumn{4}{|c|}{ Bobot kering batang dan daun (g) } & \multicolumn{4}{|c|}{ Bobot kering total tanaman $(\mathrm{g})$} \\
\hline & IM & $\mathrm{H}$ & $\mathrm{H}+20$ & $\mathrm{P}$ & $\mathrm{IM}$ & $\mathrm{H}$ & $\mathrm{H}+20$ & $\mathrm{P}$ \\
\hline \multicolumn{9}{|l|}{ Dosis urea } \\
\hline $0 \mathrm{~kg} \mathrm{ha}^{-1}$ & $7.10 \mathrm{~b}$ & $15.53 b$ & $11.63 b$ & $9.26 \mathrm{~b}$ & $7.10 \mathrm{a}$ & $18.63 b$ & $23.04 b$ & $23.00 \mathrm{a}$ \\
\hline $250 \mathrm{~kg} \mathrm{ha}^{-1}$ & $13.45 \mathrm{a}$ & $21.68 \mathrm{a}$ & $17.30 \mathrm{a}$ & $14.30 \mathrm{a}$ & $13.45 \mathrm{a}$ & $26.17 \mathrm{a}$ & $34.69 \mathrm{a}$ & $34.15 \mathrm{a}$ \\
\hline \multicolumn{9}{|l|}{ Varietas } \\
\hline Hipa 18 & $11.04 \mathrm{a}$ & $22.60 \mathrm{a}$ & $15.00 \mathrm{a}$ & $12.75 \mathrm{a}$ & $11.04 \mathrm{a}$ & $27.15 \mathrm{a}$ & $30.02 \mathrm{a}$ & $31.13 \mathrm{a}$ \\
\hline IPB 3S & $10.12 \mathrm{a}$ & $18.64 \mathrm{ab}$ & $15.30 \mathrm{a}$ & $11.53 \mathrm{a}$ & $10.12 \mathrm{a}$ & $22.62 \mathrm{ab}$ & $29.72 \mathrm{a}$ & $29.99 \mathrm{ab}$ \\
\hline Ciherang & $9.86 \mathrm{a}$ & $17.13 b$ & $13.94 \mathrm{a}$ & $12.19 \mathrm{a}$ & $9.86 \mathrm{a}$ & $20.03 b$ & $27.44 \mathrm{a}$ & $27.50 \mathrm{ab}$ \\
\hline Way Apo Buru & $10.06 \mathrm{a}$ & $16.05 b$ & $13.65 \mathrm{a}$ & $10.67 \mathrm{a}$ & $10.06 \mathrm{a}$ & $19.80 \mathrm{~b}$ & $28.28 \mathrm{a}$ & $25.68 b$ \\
\hline
\end{tabular}

Keterangan: Angka yang diikuti huruf yang sama pada kolom yang sama menunjukkan hasil yang tidak berbeda nyata berdasarkan DMRT pada $\alpha=5 \%$. IM $=$ inisiasi malai; $\mathrm{H}=$ heading; $\mathrm{H}+20=$ heading +20 hari; $\mathrm{P}=$ panen

perlakuan tidak adanya penambahan input N. Namun, respon yang ditunjukkan oleh varietas Ciherang dan Way Apo Buru berbeda dimana kedua varietas ini memiliki penurunan persentase $\mathrm{N}$ daun yang relatif sama pada pemberian pupuk urea $250 \mathrm{~kg} \mathrm{ha}^{-1}$ maupun $0 \mathrm{~kg} \mathrm{ha}^{-1}$.

Penyerapan nitrogen yang tinggi pada saat fase heading berpengaruh terhadap penundaan proses penuaan pada tanaman, yang selanjutnya dapat mengoptimalkan pengisian biji dan menghasilkan biji yang lebih tinggi (Nehe et al. 2020). Hal ini ditunjukkan oleh kandungan klorofil saat panen pada tanaman dengan dosis pemupukan urea $250 \mathrm{~kg} \mathrm{ha}^{-1}$ yang nyata lebih tinggi dibandingkan dengan perlakuan urea $0 \mathrm{~kg} \mathrm{ha}^{-1}$ (Tabel 5). Kandungan klorofil yang tinggi menyebabkan sifat stay green pada tanaman padi. Pada penelitian ini varietas Way Apo Buru memiliki kandungan klorofil yang tertinggi yang menunjukkan sifat stay green yang lebih lama dan nilainya berbeda nyata dengan kandungan klorofil IPB 3S.

Indeks luas daun mencerminkan luas daun yang menutupi suatu luasan tanah. Nilai ILD yang nyata lebih tinggi pada pemberian urea $250 \mathrm{~kg} \mathrm{ha}^{-1}$ dibandingkan dengan $0 \mathrm{~kg} \mathrm{ha}^{-1}$ (Tabel 5) mencerminkan bahwa energi matahari yang ditangkap lebih banyak pada tanaman dengan perlakuan pemberian urea yang optimum. Hal ini tentunya mempengaruhi hasil fotosintesis. Menurut Long et al. (2006) laju fotosintesis per unit area dan luas permukaan daun yang dapat menerima cahaya menjadi penentu total asimilat yang akan digunakan untuk pertumbuhan maupun untuk disimpan. Semakin luas permukaan daun yang dapat menerima cahaya, maka semakin banyak pula asimilat yang dapat diproduksi untuk pengisian biji (Mareza et al., 2016).

\section{Komponen Hasil}

Perbedaan varietas menghasilkan variasi pada masingmasing parameter komponen hasil (Tabel 6). Varietas Hipa 18 memiliki jumlah biji per tanaman yang terbesar dibandingkan dengan ketiga varietas lainnya. Hal ini mengindikasikan bahwa varietas tersebut memiliki ukuran sink yang paling besar. Kondisi ini dapat menjelaskan terjadinya akumulasi dan penurunan bobot kering batang dan daun yang paling tinggi (Tabel 2) dan penurunan NSC

Tabel 3. Kandungan NSC empat varietas padi selama fase pengisian biji pada pemberian pupuk urea

\begin{tabular}{llcc}
\hline \multirow{2}{*}{ Dosis urea dan varietas } & \multicolumn{2}{c}{ NSC per rumpun $(\mathrm{g})$} & $\mathrm{P}$ \\
\cline { 2 - 4 } & $\mathrm{H}$ & $\mathrm{H}+20$ & $4.68 \mathrm{~b}$ \\
\hline Dosis urea & $5.40 \mathrm{~b}$ & $6.00 \mathrm{~b}$ & $7.35 \mathrm{a}$ \\
$0 \mathrm{~kg} \mathrm{ha}^{-1}$ & $8.50 \mathrm{a}$ & $8.93 \mathrm{a}$ & $6.46 \mathrm{a}$ \\
$250 \mathrm{~kg} \mathrm{ha}^{-1}$ & & & $5.67 \mathrm{a}$ \\
Varietas & $7.93 \mathrm{a}$ & $7.43 \mathrm{a}$ & $6.33 \mathrm{a}$ \\
Hipa 18 & $7.21 \mathrm{ab}$ & $8.31 \mathrm{a}$ & $5.61 \mathrm{a}$ \\
IPB 3S & $6.8 \mathrm{ab}$ & $6.94 \mathrm{a}$ & $7.15 \mathrm{a}$ \\
Ciherang & $5.87 \mathrm{~b}$ & & \\
Way Apo Buru & &
\end{tabular}

Keterangan: Angka yang diikuti huruf yang sama pada kolom yang sama menunjukkan hasil yang tidak berbeda nyata berdasarkan DMRT pada $\alpha=5 \%$. $\mathrm{H}=$ heading; $\mathrm{H}+20=$ heading +20 hari; $\mathrm{P}=$ panen 
Tabel 4. Kandungan N daun empat varietas padi pada inisiasi malai dan heading pada pemberian pupuk urea

\begin{tabular}{lcccc}
\hline \multirow{2}{*}{ Varietas/Dosis urea } & \multicolumn{2}{c}{$\mathrm{N}(\%)$ inisiasi malai } & \multicolumn{2}{c}{$\mathrm{N}(\%)$ heading } \\
\cline { 2 - 5 } & $0 \mathrm{~kg} \mathrm{ha}^{-1}$ & $250 \mathrm{~kg} \mathrm{ha}^{-1}$ & $250 \mathrm{~kg} \mathrm{ha}^{-1}$ \\
\hline Hipa 18 & $2.18 \mathrm{c}$ & $2.98 \mathrm{a}$ & $1.48 \mathrm{e}$ & $1.71 \mathrm{~cd}$ \\
IPB 3S & $2.24 \mathrm{c}$ & $2.78 \mathrm{a}$ & $1.60 \mathrm{de}$ & $1.83 \mathrm{bc}$ \\
Ciherang & $2.18 \mathrm{c}$ & $2.97 \mathrm{a}$ & $1.56 \mathrm{de}$ & $2.31 \mathrm{a}$ \\
Way Apo Buru & $2.18 \mathrm{c}$ & $2.56 \mathrm{~b}$ & $1.53 \mathrm{de}$ & $1.91 \mathrm{~b}$ \\
\hline
\end{tabular}

Keterangan: Angka yang diikuti huruf yang sama menunjukkan hasil yang tidak berbeda nyata berdasarkan DMRT pada $\alpha=5 \%$

Tabel 5. Klorofil dan indeks luas daun empat varietas padi selama fase pengisian biji pada pemberian pupuk urea

\begin{tabular}{|c|c|c|c|c|c|c|c|}
\hline \multirow{2}{*}{ Dosis urea dan varietas } & \multicolumn{4}{|c|}{ Klorofil $\left(\mu \mathrm{mol} \mathrm{m}{ }^{-2}\right)$} & \multicolumn{3}{|c|}{ Indeks luas daun } \\
\hline & IM & $\mathrm{H}$ & $\mathrm{H}+20$ & $\mathrm{P}$ & $\mathrm{H}$ & $\mathrm{H}+20$ & $\mathrm{P}$ \\
\hline \multicolumn{8}{|l|}{ Dosis urea } \\
\hline $0 \mathrm{~kg} \mathrm{ha}^{-1}$ & $25.48 b$ & $24.76 b$ & $18.51 \mathrm{~b}$ & $15.04 \mathrm{~b}$ & $1.49 \mathrm{~b}$ & $0.97 \mathrm{~b}$ & $0.78 b$ \\
\hline $250 \mathrm{~kg} \mathrm{ha}^{-1}$ & $34.75 \mathrm{a}$ & $34.64 a$ & $28.14 \mathrm{a}$ & $22.30 \mathrm{a}$ & $2.57 \mathrm{a}$ & $1.79 \mathrm{a}$ & $1.53 \mathrm{a}$ \\
\hline \multicolumn{8}{|l|}{ Varietas } \\
\hline Hipa 18 & $30.76 a$ & $29.49 a$ & $24.14 \mathrm{ab}$ & $18.53 \mathrm{ab}$ & $2.50 \mathrm{a}$ & $1.60 \mathrm{a}$ & $1.23 \mathrm{a}$ \\
\hline IPB 3S & $30.31 \mathrm{a}$ & $28.51 \mathrm{a}$ & $20.15 b$ & $17.27 \mathrm{~b}$ & $1.89 \mathrm{ab}$ & $1.33 \mathrm{a}$ & $1.11 \mathrm{a}$ \\
\hline Ciherang & $30.10 \mathrm{a}$ & $29.36 \mathrm{a}$ & $23.47 \mathrm{ab}$ & $17.90 \mathrm{ab}$ & $1.99 \mathrm{ab}$ & $1.41 \mathrm{a}$ & $1.16 \mathrm{a}$ \\
\hline Way Apo Buru & $29.00 \mathrm{a}$ & $31.43 \mathrm{a}$ & $25.55 \mathrm{a}$ & $20.97 \mathrm{a}$ & $1.73 b$ & $1.19 \mathrm{a}$ & $1.13 \mathrm{a}$ \\
\hline
\end{tabular}

Keterangan: Angka yang diikuti huruf yang sama pada kolom yang sama menunjukkan hasil yang tidak berbeda nyata berdasarkan DMRT pada $\alpha=5 \%$. IM $=$ inisiasi malai, $\mathrm{H}=$ heading, $\mathrm{H}+20=$ heading +20 hari, $\mathrm{P}=$ panen

pada batang yang lebih cepat pada varietas Hipa 18 (Tabel 3). Hal ini diduga akibat kebutuhan sink yang besar. Hal lain yang menarik pada penelitian ini adalah bahwa varietas Hipa 18 pada dasarnya memiliki bobot 100 biji yang paling rendah dan berbeda nyata dengan ketiga varietas lain, sedangkan varietas Way Apo Buru memiliki bobot 100 biji yang tertinggi. Dengan kata lain, Way Apo Buru memiliki biji yang lebih berat dibandingkan dengan Hipa 18. Namun demikian, varietas Hipa 18 memiliki jumlah biji total per rumpun yang nyata lebih tinggi dibandingkan dengan Way Apo Buru, sehingga bobot biji per rumpun varietas Hipa 18 juga nyata lebih tinggi dibandingkan dengan varietas Way Apo Buru.

Pemberian urea dengan dosis $250 \mathrm{~kg} \mathrm{ha}^{-1}$ pada lahan percobaan memberikan hasil yang nyata lebih tinggi pada semua komponen hasil yang diamati. Menurut Yang et al.

Tabel 6. Komponen hasil empat varietas padi pada pemberian pupuk urea

\begin{tabular}{|c|c|c|c|c|c|c|}
\hline \multirow[b]{2}{*}{ Dosis urea dan varietas } & \multicolumn{5}{|c|}{ Komponen hasil } & \multirow[b]{2}{*}{$\begin{array}{c}\text { Produktivitas } \\
\left(\text { ton } \mathrm{ha}^{-1}\right)\end{array}$} \\
\hline & $\begin{array}{l}\text { Jumlah malai } \\
\text { per rumpun }\end{array}$ & $\begin{array}{l}\text { Jumlah biji } \\
\text { per rumpun }\end{array}$ & $\begin{array}{c}\text { Bobot } 100 \\
\text { biji }(\mathrm{g})\end{array}$ & $\begin{array}{l}\text { Bobot biji bernas } \\
\text { per rumpun }(\mathrm{g})\end{array}$ & $\begin{array}{l}\text { Bobot biji total } \\
\text { per rumpun }(\mathrm{g})\end{array}$ & \\
\hline \multicolumn{7}{|l|}{ Dosis urea } \\
\hline $0 \mathrm{~kg} \mathrm{ha}^{-1}$ & $10.86 b$ & $658.92 b$ & $2.37 b$ & $8.58 b$ & $11.55 \mathrm{~b}$ & $2.92 b$ \\
\hline $250 \mathrm{~kg} \mathrm{ha}^{-1}$ & $14.47 \mathrm{a}$ & $1,042.06 \mathrm{a}$ & $2.62 \mathrm{a}$ & $15.63 \mathrm{a}$ & $21.22 \mathrm{a}$ & $4.31 \mathrm{a}$ \\
\hline \multicolumn{7}{|l|}{ Varietas } \\
\hline Hipa 18 & $13.61 \mathrm{a}$ & $1,037.22 \mathrm{a}$ & $2.27 \mathrm{~b}$ & $13.29 \mathrm{a}$ & $19.27 \mathrm{a}$ & $3.97 \mathrm{a}$ \\
\hline IPB 3S & $11.00 \mathrm{~b}$ & $869.67 b$ & $2.50 \mathrm{a}$ & $12.11 \mathrm{a}$ & $16.45 \mathrm{ab}$ & $3.89 \mathrm{a}$ \\
\hline Ciherang & $12.28 \mathrm{ab}$ & $759.56 b$ & $2.57 \mathrm{a}$ & $11.73 \mathrm{a}$ & $15.19 \mathrm{ab}$ & $3.65 \mathrm{ab}$ \\
\hline Way Apo Buru & $13.78 \mathrm{a}$ & $735.50 \mathrm{~b}$ & $2.63 \mathrm{a}$ & $11.30 \mathrm{a}$ & $14.64 b$ & $2.94 b$ \\
\hline
\end{tabular}

Keterangan: Angka yang diikuti huruf yang sama pada kolom yang sama menunjukkan hasil yang tidak berbeda nyata berdasarkan DMRT pada $\alpha=5 \%$ 
(2020) nitrogen mampu memberikan pengaruh yang nyata terhadap akumulasi dan sifat fisikokimia pati. Aplikasi nitrogen mendorong akumulasi pati di antara bagianbagian endosperma yang akhirnya mempengaruhi sifat agronomi padi. Hal ini sesuai dengan analisis korelasi yang menunjukkan bahwa bobot dan jumlah biji per rumpun berkorelasi positif dengan semua parameter pertumbuhan yang dipengaruhi oleh unsur N (Tabel 7).

Parameter pertumbuhan seperti kandungan $\mathrm{N}$ daun, klorofil, dan ILD berhubungan erat dengan hasil asimilat yang disimpan di dalam biji karena mempunyai pengaruh terhadap laju fotosintesis. Bobot kering batang dan daun juga berkorelasi positif dengan bobot dan jumlah biji per rumpun karena merupakan sumber asimilat yang diremobilisasi ke biji. Koefisien korelasi bobot dan jumlah biji per rumpun dengan kandungan nitrogen daun dan klorofil pada saat inisiasi malai lebih tinggi dibandingkan pada saat heading. Hal ini menunjukkan bahwa kandungan $\mathrm{N}$ daun dan klorofil pada inisiasi malai lebih mempengaruhi nilai bobot biji total dan jumlah biji per tanaman. Kebutuhan nitrogen pada tahap inisiasi malai sangat penting karena secara nyata dapat menurunkan jumlah amilosa sehingga terjadi peningkatan permintaan pati oleh biji (Yang et al., 2020). Meskipun demikian, kedua karakter tersebut tetap memiliki peranan penting pada saat heading.
Remobilisasi $\mathrm{N}$ dari daun akan terus berlangsung setelah heading. Hal ini menyebabkan terjadinya penurunan asam amino bebas dan asam amino protein pada daun sehingga terjadi inisiasi penuaan daun selama masa pengisian biji (Zhao et al., 2015). Kondisi $\mathrm{N}$ yang tidak mencukupi bagi tanaman dapat menginduksi penuaan tanaman yang disebabkan oleh terjadinya degradasi pada komponen $\mathrm{N}$ dan akan mempengaruhi hasil tanaman (Mu dan Chen, 2021). Ketika penuaan dihambat akibat tercukupinya kebutuhan unsur N, ILD juga akan dapat dipertahankan sehingga penyerapan energi matahari akan lebih optimal. Hal ini dibuktikan dengan nilai ILD yang berkorelasi positif dengan kandungan $\mathrm{N}$ daun dan klorofil.

Bobot 100 biji memiliki korelasi positif yang lemah dengan hampir seluruh karakter pertumbuhan karena koefisien korelasi yang lebih kecil dari 0.5, bahkan tidak berkorelasi dengan tinggi tanaman saat panen, bobot kering batang dan daun saat heading, dan ILD. Menurut Sution dan Serom (2019) ukuran biji lebih dipengaruhi oleh genetik dan interaksi dengan lingkungan tumbuhnya. Kaihatu dan Pesireron (2011) menambahkan faktor lain seperti kompetisi antar biji pada tanaman padi dapat mempengaruhi ukuran biji. Semakin banyak biji yang dihasilkan, maka kompetisi untuk mendapatkan asimilat akan semakin tinggi yang akan menyebabkan ukuran biji dapat mengecil.

Tabel 7. Koefisien korelasi karakter vegetatif dan komponen hasil empat varietas padi pada pemberian pupuk urea

\begin{tabular}{|c|c|c|c|c|c|c|c|c|c|c|c|}
\hline Peubah & JAM & $\mathrm{BDH}$ & BDP & NIM & $\mathrm{NH}$ & KIM & $\mathrm{KH}$ & ILD & $\mathrm{BG}$ & $100 \mathrm{bt}$ & $\mathrm{JG}$ \\
\hline TTP & 0,08 & $0.67 * *$ & $0.49 * *$ & $0.65 * *$ & $0.26^{*}$ & $0.57 * *$ & $0.37 * *$ & $0.54 * *$ & $0.73 * *$ & 0.19 & $0.71 * *$ \\
\hline JAM & & $0.39 * *$ & $0.50 * *$ & $0.64 * *$ & $0.51 * *$ & $0.55 * *$ & $0.69 * *$ & $0.59 * *$ & $0.60 * *$ & $0.26^{*}$ & $0.60 * *$ \\
\hline $\mathrm{BDH}$ & & & $0.50 * *$ & $0.58 * *$ & $0.24^{*}$ & $0.52 * *$ & $0.41 * *$ & $0.54 * *$ & $0.67 * *$ & 0.08 & $0.66^{* *}$ \\
\hline BDP & & & & $0.76 * *$ & $0.54 * *$ & $0.60 * *$ & $0.60 * *$ & $0.47 * *$ & $0.65^{* *}$ & $0.39 * *$ & $0.62 * *$ \\
\hline NIM & & & & & $0.72 * *$ & $0.83 * *$ & $0.79 * *$ & $0.72 * *$ & $0.80 * *$ & $0.44 * *$ & $0.84 * *$ \\
\hline $\mathrm{NH}$ & & & & & & $0.67 * *$ & $0.67 * *$ & $0.45 * *$ & $0.49 * *$ & $0.50 * *$ & $0.43 * *$ \\
\hline KIM & & & & & & & $0.67 * *$ & $0.67 * *$ & $0.76^{* *}$ & $0.40 * *$ & $0.77 * *$ \\
\hline $\mathrm{KH}$ & & & & & & & & $0.54 * *$ & $0.63 * *$ & $0.41 * *$ & $0.65 * *$ \\
\hline ILD & & & & & & & & & $0.69 * *$ & 0.23 & $0.80 * *$ \\
\hline $\mathrm{BG}$ & & & & & & & & & & $0.36 * *$ & $0.87 * *$ \\
\hline $100 \mathrm{bt}$ & & & & & & & & & & & $0.26^{*}$ \\
\hline
\end{tabular}

Keterangan: $*=$ korelasi nyata pada $\alpha=0.05 ; * *$ korelasi nyata pada $\alpha=0.01 ; \mathrm{TTP}=$ tinggi tanaman saat panen; JAM $=$ jumlah anakan maksimum; $\mathrm{BDH}$ = bobot kering batang dan daun saat heading; $\mathrm{BDP}=$ bobot kering batang dan daun saat panen; NIM = kandungan $\mathrm{N}$ daun saat inisiasi malai; $\mathrm{NH}=$ kandungan $\mathrm{N}$ daun saat heading; $\mathrm{KIM}=$ klorofil saat inisiasi malai; $\mathrm{KH}=\mathrm{klorofil}$ saat heading; ILD = indeks luas daun; $\mathrm{BG}=$ bobot biji per rumpun; $100 \mathrm{bt}=$ bobot $100 \mathrm{biji}$ JG = jumlah biji per rumpun

\section{KESIMPULAN}

Karakter pengisian biji yang paling berbeda diantara keempat varietas yang digunakan dalam penelitian ini adalah varietas Hipa 18. Hipa 18 melakukan remobilisasi asimilat dalam jumlah yang paling tinggi dan lebih cepat dibandingkan ketiga varietas lainnya selama fase pengisian biji untuk memenuhi kebutuhan sink-nya yang besar. Varietas ini menggunakan $\mathrm{N}$ daun dalam jumlah yang paling tinggi untuk pembentukan dan perkembangan malainya, sementara itu Ciherang menggunakannya dengan jumlah yang paling sedikit. Hipa 18 memiliki jumlah malai, jumlah biji, bobot biji, dan bobot biji bernas per rumpun yang paling tinggi, namun bobot 100 butir yang paling rendah. Bobot 100 biji tertinggi didapat dari varietas Way Apo Buru. Hasil biji berkorelasi positif dengan karakter pertumbuhan seperti bobot kering batang dan daun, kandungan $\mathrm{N}$ daun, klrofil, dan indeks luas daun. Hasil penelitian ini dapat 
digunakan sebagai dasar pengembangan varietas berpotensi hasil tinggi dan rekomendasi pemupukan yang lebih presisi untuk masing-masing varietas.

\section{DAFTAR PUSTAKA}

Alavan, A., R. Hayati, H. Erita. 2015. Pengaruh pemupukan terhadap pertumbuhan beberapa varietas padi sawah (Oryza sativa L.). J. Floratek. 10:61-68.

Elizabeth, R. 2011. Strategi pencapaian diversifikasi dan lemandirian pangan: antara harapan dan kenyataan. Iptek Tanam. Pangan. 6:230-242.

Huang, L., D. Yang, X. Li, S. Peng, F. Wang. 2019. Coordination of high grain yield and high nitrogen use efficiency through large sink size and high postheading source capacity in rice. F. Crop. Res. 233:4958.

Kaihatu, S.S., M. Pesireron. 2011. Adaptasi beberapa varietas unggul baru padi sawah di morokai. J. Agrivigor. 11:178-184.

Kartina, N.B.P. Wibowo, Y. Widyastuti, I.A. Rumanti, Satoto. 2016. Korelasi dan sidik lintas karakter agronomi padi hibrida. J. Ilmu Pertan. Indonesia 21:76-83.

Li, G., J. Pan, K. Cui, M. Yuan, Q. Hu, W. Wang, P. K. Mohapatra, L. Nie, J. Huang, S. Peng. 2017. Limitation of unloading in the developing grains is a possible cause responsible for low stem non-structural carbohydrate translocation and poor grain yield formation in rice through verification of recombinant inbred lines. Front. Plant Sci. 8:1-16.

Liang, W., Z. Zhang, X. Wen, Y. Liao, Y. Liu. 2017. Effect of non-structural carbohydrate accumulation in the stem pre-anthesis on grain filling of wheat inferior grain. F. Crop. Res. 211:66-76.

Long, S.P., X.G. Zhu, S.L. Naidu, D.R. Ort. 2006. Can improvement in photosynthesis increase crop yields? Plant, Cell Environ. 29:315-330.

Lubis, I., M. Ohnisi, K. Katsura, T. Shiraiwa. 2013. Plant factors related to dry matter production. J. ISSAAS. 19:58-67.

Mareza, E., Z.R. Djafar, R.A. Suwignyo, D.A. Wijaya. 2016. Morfofisiologi ratun padi sistem tanam benih langsung di lahan pasang surut. J. Agron. Indonesia 44:228-234.
Mu, X., Y. Chen. 2021. The physiological response of photosynthesis to nitrogen deficiency. Plant Physiol. Biochem. 158:76-82.

Nehe, A.S., S. Misra, E.H. Murchie, K. Chinnathambi, B. S. Tyagi, M.J. Foulkes. 2020. Nitrogen partitioning and remobilization in relation to leaf senescence, grain yield and protein concentration in Indian wheat cultivars. F. Crop. Res. 251:107778.

Li, D.Q., Q.Y. Tang, Y.B. Zhang, J.Q. Qin, H. Li, L.J. Chen, S.H. Yang, Y.B. Zou, S.B. Peng. 2012. Effect of nitrogen regimes on grain yield, nitrogen utilization, radiation use efficiency, and sheath blight disease intensity in super hybrid rice. J. Integr. Agric. 11:134143.

Longland, A.C., B.M. Byrd. 2006. Pasture nonstructural carbohydrate and equine laminitis. J. Nutr. $136(7$ Suppl):2099S-2102S.

Slewinski, T.L. 2012. In Posidonia oceanica cadmium induces changes in DNA methylation and chromatin patterning. J. Exp. Bot. 63:695-709.

Sution, Serom. 2019. Pengaruh umur bibit dan jumlah bibit terhadap produktivitas padi sawah. J. Pertan. Agros. 21:100-107.

Vijayalakshmi, P., T.V. Kiran, Y.V. Rao, B. Srikanth, I.S. Rao, B. Sailaja, K. Surekha, P.R. Rao, D. Subrahmanyam, C.N. Neeraja, S.R. Voleti. 2013. Physiological approaches for increasing nitrogen use efficiency in rice. Indian J. Plant Physiol. 18:208-222.

Wang, D.R., R. Han, E.J. Wolfrum, S.R. McCouch. 2017. The buffering capacity of stems: genetic architecture of nonstructural carbohydrates in cultivated Asian rice, Oryza sativa. New Phytol. 215:658-671.

Xi, L., L. Yong. 2016. Varietal difference in the correlation between leaf nitrogen content and photosynthesis in rice (Oryza sativa L.) plants is related to specific leaf weight. J. Integr. Agric. 15:2002-2011.

Yang, Y., G. Lin, X. Yu, Y. Wu, F. Xiong. 2020. Rice starch accumulation at different endosperm regions and physical properties under nitrogen treatment at panicle initiation stage. Int. J. Biol. Macromol. 160:328-339.

Zhao, Y., M. Xi, X. Zhang, Z. Lin, C. Ding, S. Tang, Z. Liu, S. Wang, Y. Ding. 2015. Nitrogen effect on amino acid composition in leaf and grain of japonica rice during grain filling stage. J. Cereal Sci. 64:29-33. 